\title{
Leaf litter input and electrical conductivity may change density of Phylloicus sp. (Trichoptera: Calamoceratidae) in a Brazilian savannah stream
}

\author{
Entrada de detritus foliares e condutividade elétrica afetam a densidade de Phylloicus sp. \\ (Trichoptera: Calamoceratidae) em um riacho de cabeceira no Cerrado
}

\author{
Gustavo Figueiredo Marques Leite ${ }^{1 *}$, Fabíola Turiel Costa Silva ${ }^{1,2}$, \\ Fernanda Keley Silva Pereira Navarro ${ }^{1,3}$, Renan de Souza Rezende ${ }^{1,4}$ and \\ José Francisco Gonçalves Júnior ${ }^{1}$
}

\begin{abstract}
${ }^{1}$ Departamento de Ecologia, Universidade de Brasília - UnB, Campus Universitário Darcy Ribeiro, Asa Norte, CEP 70910-900, Brasília, DF, Brazil

${ }^{2}$ Departamento de Genética e Morfologia, Universidade de Brasília - UnB, Campus Universitário Darcy Ribeiro, Asa Norte, CEP 70910-900, Brasília, DF, Brazil

${ }^{3}$ Instituto Federal de Educação, Ciência e Tecnologia de Goiás - IFES-GO, Campus Águas Lindas, CEP 72910-733, Águas Lindas de Goiás, GO, Brazil

${ }^{4}$ Programa de Pós-graduação em Ecologia e Conservação, Universidade Estadual do Mato

Grosso - UNEMAT, CEP 78690-000, Nova Xavantina, MT, Brazil

*e-mail: gfmleite@gmail.com
\end{abstract}

Cite as: Leite, G.F.M. et al. Leaf litter input and electrical conductivity may change density of Phylloicus sp. (Trichoptera: Calamoceratidae) in a Brazilian savannah stream. Acta Limnologica Brasiliensia, 2016, vol. 28, e12.

\begin{abstract}
Aim: Shredders are generally not abundant in tropical streams, and there is considerable evidence suggesting that the food supply drives this pattern in headwaters. The aim of this study was to assess the effect of variation in the availability of food resources, over one year, on the density of Phylloicus sp. (Trichoptera: Calamoceratidae), which is one of the main shredders in Neotropical headwaters. Methods: We measured the relative importance of organic matter in terms of vertical input (VI) and benthic standing stock (BS) on Phylloicus sp. density from October 2012 to September 2013 in a preserved third order stream in the Cerrado savannah biome, Federal District, Brazil. Results: Leaves were abundant (monthly biomass of 24.2 g.m $\mathrm{m}^{-2} \pm 23.1 \mathrm{SD}$ in VI and $46.1 \mathrm{~g} . \mathrm{m}^{-2} \pm 76.7 \mathrm{SD}$ in BS), increasing at the end of dry season (August to October) and comprised the most abundant fraction in VI and BS $(-70 \%)$. Phylloicus sp. had a low density throughout the year (2.4 ind. $\left.\mathrm{m}^{-2} \pm 4.9 \mathrm{SD}\right)$ and its peak (13.7 ind. $\mathrm{m}^{-2} \pm 17.1 \mathrm{SD}$ in October) was associated with greater leaf biomass in VI and high electrical conductivity in the stream. The well-defined peak of Phylloicus sp. density in October suggests interplay between the increase in Phylloicus density and the leaf litter that enters the stream at the end of the dry season. Electrical conductivity was also higher in October, reflecting an increase in nutrient concentrations in the water during this period. Conclusions: The availability of leaf litter may be a determinant factor for the seasonal variation in Phylloicus sp. density in tropical streams, suggesting a bottom-up effect. Changes in the supply of allochthonous resources to the stream can lead to modification in populations of shredders, such as Phylloicus sp., and anthropogenic influences on the riparian vegetation can affect ecological processes of great importance to streams.
\end{abstract}

Keywords: caddisfly; organic matter dynamics; tropical shredders; headwaters; Cerrado. 
Resumo: Objetivo: Invertebrados fragmentadores são geralmente escassos em riachos tropicais, com evidências consideráveis sugerindo que a disponibilidade de recursos alimentares possa determinar esse padrão em riachos de cabeceira. $\mathrm{O}$ objetivo desse estudo foi avaliar os efeitos de variaçóes na disponibilidade de recursos alimentares durante um ano na densidade Phylloicus sp. (Trichoptera: Calamoceratidae), o qual está entre os principais invertebrados fragmentadores em riachos de cabeceira neotropicais. Métodos: Medimos a importância relativa da matéria orgânica vegetal alóctone em termos de entrada vertical (EV) e estoque bêntico (EB) na densidade de Phylloicus sp., entre outubro de 2012 e setembro de 2013, em um riacho preservado de terceira ordem no Cerrado, Distrito Federal, Brasil. Resultados: Folhas foi a fração mais abundante na EV e EB ( $70 \%)$. A biomassa de folhas foi alta durante todo o ano (biomassa mensal de $24,2 \mathrm{~g} \cdot \mathrm{m}^{-2} \pm 23,1 \mathrm{SD}$ na EV e $46,1 \mathrm{~g} \cdot \mathrm{m}^{-2} \pm 76,7 \mathrm{SD}$ no EB), aumentando ao final da estação seca (agosto a outubro). Phylloicus sp. Teve baixa densidade durante $\mathrm{o}$ ano $\left(2,4 \pm 4,9\right.$ ind. $\mathrm{m}^{-2}$ média $\left.\pm \mathrm{DP}\right)$ e seu pico foi associado à maior biomassa de folhas na EV e maior condutividade elétrica no riacho. O pico bem definido de Phylloicus sp. em outubro sugere uma interação entre o aumento densidade de Phylloicus sp. e a entrada de folhas no final da estação seca. A condutividade elétrica também foi maior em outubro, refletindo um aumento nas concentraçôes de nutrientes na água durante esse período. Conclusóes: A disponibilidade de detritos foliares pode ser um fator determinante para a densidade sazonal de Phylloicus sp., sugerindo um efeito bottom-up em riachos tropicais. Mudanças no suprimento de recursos alóctones em riachos podem afetar as populaçóes de fragmentadores como Phylloicus sp. e influências antropogênicas na vegetaçáo ripária podem afetar processos ecológicos de grande importância para riachos de cabeceira.

Palavras-chave: Trichoptera; dinâmica de matéria orgânica; fragmentadores tropicais; riachos de cabeceira; Cerrado.

\section{Introduction}

Allochthonous detritus is the major energy source for food webs in forested headwater streams due to low light penetration and consequently low in-stream primary production (Cummins, 1975). Microorganisms (fungi and bacteria) and invertebrate shredders break down the detritus that enters streams, converting the coarse particulate organic matter (CPOM) to fine particulate organic matter (FPOM) and connecting the riparian vegetation to the aquatic food web (Abelho, 2001; Tank et al., 2010). Several studies have demonstrated the importance of shredders in the decomposition of leaf detritus in temperate streams (Webster $\&$ Benfield, 1986; Graça, 2001; Haapala et al., 2001). However, the role of shredders in litter processing in tropical streams is controversial, with some studies showing their importance (Moretti et al., 2009; Tonin et al., 2014; Rezende et al., 2014), but not others (Moretti et al., 2007; Gonçalves Júnior et al., 2012a, b).

In the Brazilian savannah, leaf abscission is seasonal, increasing at the end of the dry season and the beginning of the rainy season (Gonçalves Júnior et al., 2006; Gonçalves Júnior \& Callisto, 2013). The leaf litter that enters the stream accumulates on the streambed and is colonized by organisms that use the litter for feeding or case building (Kobayashi \& Kagaya, 2004, 2005; Ligeiro et al., 2010). Aquatic invertebrates quickly respond to aggregations of food resources in the stream, turning leaf detritus patches into hotspots of biodiversity (Kobayashi \& Kagaya, 2004, 2005). There is considerable evidence suggesting that the availability and quality of the food supply are positively related to population parameters (e.g. growth rate, secondary productivity, density) of benthic shredders (Grafius \& Anderson, 1980; Richardson, 1993; Graça, 2001). For instance, Grafius \& Anderson (1979) showed that the growth and population productivity of the shredder Lepidostoma quercina Ross, 1938 is limited by the lack of good quality leaves as a food resource. Although tropical shredders are generally not abundant in tropical streams, their importance has been tested in experimental studies focusing primarily on the genus Phylloicus (Becker et al., 2009; Moretti et al., 2009; Navarro et al., 2013; Rezende et al., 2015).

The caddisfly genus Phylloicus Müller, 1880 (Trichoptera: Calamoceratidae) has 61 species, distributed from South America to Central America and with high diversity in Brazil, Peru and Venezuela (Prather, 2003). This genus is important among tropical invertebrate shredders (Graça, 2001; Rezende et al., 2014) due to larger body size when compared to other species, which results in higher per capita consumption rates (Tonin et al., 2014). Phylloicus spp. larvae are commonly found on submerged leaves, using leaf resources for feeding and case building (Graça, 2001; Moretti et al., 2009). Previous studies demonstrated 
that detritus quality (Wantzen \& Wagner, 2006; Moretti et al., 2009), environmental conditions (e.g., physical and chemical characteristics of the water; Navarro et al., 2013; Pes et al., 2013) and biological interactions (e.g. competition and predation; Boyero \& Pearson, 2006; Allan et al., 2009; Rezende et al., 2015) can affect the feeding behavior of Phylloicus. Therefore, events such as temporal changes in leaf litter input (Benson \& Pearson, 1993; França et al., 2009; Gonçalves Júnior \& Callisto, 2013; Gonçalves Júnior et al., 2014), as well as the physical environment (Boyero et al., 2011; Navarro et al., 2013), have been claimed to affect shredder populations. However, there are no studies in tropical streams assessing shredder population dynamics throughout a complete hydrological cycle. Thus, the aim of this study was to assess the effect of variation in the availability of food resources throughout a year on the density of Phylloicus sp.. Our hypothesis is that the density of Phylloicus is positively related to temporal variation in allochthonous organic matter, with higher densities in months with greater quantities of $\mathrm{CPOM}$ in the stream.

\section{Material and Methods}

\subsection{Study area}

The study was carried out between October 2012 and September 2013 along 100 meters of Capetinga stream ( $-15^{\circ} 57^{\prime} 40.75^{\prime \prime} \mathrm{S}-47^{\circ} 56^{\prime} 37.80^{\prime \prime} \mathrm{W}$, $1100 \mathrm{~m}$ a.s.l.). This $3^{\text {rd }}$ order stream is close to Brasília city (Brazil's Federal Capital), located within the Area of Environmental Protection Gama and Cabeça-de-Veado, in the Paraná watershed, Central-Western Brazil. The climate in this region is Tropical Savannah, with twowell-distinguished seasons: a cold (mean temperature $20.3^{\circ} \mathrm{C} \pm 0.6 \mathrm{SD}$ ) and dry season (mean monthly rainfall $2.5 \mathrm{~mm} \pm 3.5 \mathrm{SD}$ ) from April to September, and warm (mean temperature $22.1{ }^{\circ} \mathrm{C} \pm 1.1 \mathrm{SD}$ ) and rainy season (mean monthly rainfall $197.5 \mathrm{~mm} \pm 60.2 \mathrm{SD}$ ) from October to March. The canopy, assessed from hemispherical photographs [digital camera (Nikon D5100) with a $10-\mathrm{mm}$ Fisheye lens (Sigma)] in the stream reach, varies between 11.7 to $14.1 \%$ in openness, with riparian vegetation composed mainly of trees and low emergent species. The most abundant species in the riparian vegetation are Licania apetala (E.Mey.) Fritsch, Calyptranthes clusiifolia O.Berg, Myrcia tenuifolia (O.Berg) Sobral and Vochysia pyramidalis Mart.

\subsection{Physical and chemical water parameters}

Dissolved oxygen (mg. ${ }^{-1}$; Jenway970 Meter $\mathrm{DO}_{2}$ ), turbidity (NTU; Quimis Q279P), conductivity $\left(\mu \mathrm{S} . \mathrm{cm}^{-1}\right), \mathrm{pH}$ (Jenway $430 \mathrm{pH} /$ cond. meter) and water temperature $\left({ }^{\circ} \mathrm{C}\right)$ were measured monthly with three replicates. The depth $(\mathrm{m})$ and average flow speed $\left(\mathrm{m} \cdot \mathrm{s}^{-1}\right)$ of the right, left and central portions of the watercourse were measured with a portable flowmeter (Global Water, model FP 101, College Station, TX, USA) and the discharge $\left(\mathrm{m}^{3} \cdot \mathrm{s}^{-1}\right)$ was then calculated. Monthly-accumulated rainfall $(\mathrm{mm})$ was obtained from an area $5.5 \mathrm{~km}$ near the stream (Brazilian Institute of Statistics and Geography - RECOR).

\subsection{Particulate organic matter inputs}

The availability of food resources was defined as the total or fraction (branches, leaves, reproductive parts and organic debris) of coarse particulate organic matter (CPOM) derived from vegetation in the vertical input (VI) and benthic standing stock (BS). The VI was quantified monthly by placing baskets (0.26 m diameter each), suspended $2 \mathrm{~m}$ above the stream and stretching from one bank to the other at five distinct sampling plots located every $20 \mathrm{~m}$ of the stream (Figure 1). Each plot had 18 baskets (3 lines of 6 baskets), with a total area of $0.9 \mathrm{~m}^{2}$ per plot. The BS was sampled using a Surber sampler $\left(0.27 \mathrm{~m}^{2}, 0.25 \mathrm{~mm}\right.$ of mesh) with three random replicates in each plot (total area of $4.05 \mathrm{~m}^{2}$ ). Each sample of CPOM (VI and BS) was dried at $60{ }^{\circ} \mathrm{C}$ for $72 \mathrm{~h}$, and detritus were classified in four fractions: leaves, branches, reproductive parts (fruits, flowers and seeds) and organic debris (miscellaneous detritus of non-classifiable organic

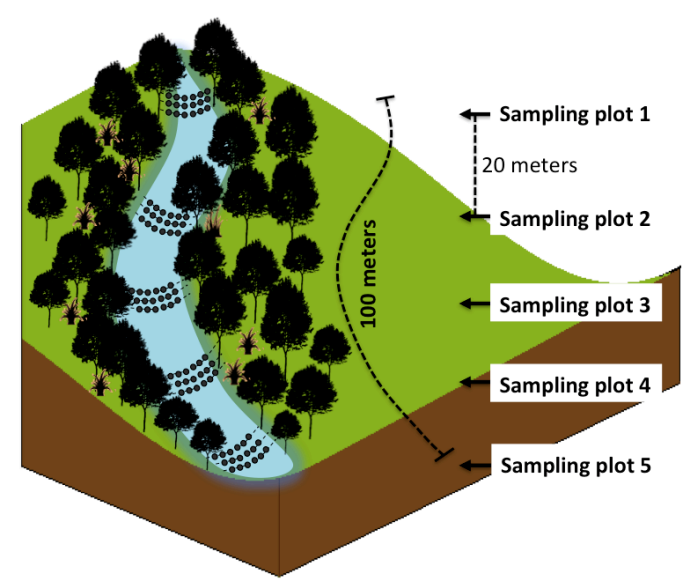

Figure 1. Experimental design with sampling plot along the stream and baskets to quantify the coarse particulate organic matter derived from vegetation in the vertical input. 
matter fractions), and weighed. Results were expressed as g. $\mathrm{m}^{-2}$.

\subsection{Density of Phylloicus}

Phylloicus counts were made in 30 quadrats $\left(0.25 \mathrm{~m}^{2}\right.$ each $)$ at random sampling plots along the stream reach, totaling an area of $7.5 \mathrm{~m}^{2}$. The quadrats were positioned along the stream to represent heterogeneous conditions: 10 quadrats in riffles, 10 in pools and 10 in leaf deposition zones. Phylloicus sp. individuals were sampled within the quadrats through active searching. In each quadrat, the individuals were counted and returned to where they were found to avoid depopulation. Searching and counting were carried out carefully, avoiding removal of leaves from the substrate in order to minimize disturbance. We did not identify any negative effects of handling quadrats on the density of Phylloicus sp.

\subsection{Data treatment}

A multivariate regression tree (MRT) was performed to determine the influence of the physical and chemical water parameters and VI and BS on the density of Phylloicus sp. (significance level of 0.05). This analysis selects the explanatory variable that best partitions the data in two homogeneous groups in respect to the values of the response variable. Each subgroup is then partitioned again, using the explanatory variable that best reduces the error within the two subgroups of data. The explanatory variable used in this second partition may be that used in the first split. This process of partitioning is known as growing the tree and continues until the number of observations in each subgroup is considered small. These partitions of data minimize the sum of squares distances (SSD) between all pairs of sites within the nodes, and maximize the SSD between all pairs of sites in different nodes (De'ath, 2002). This statistical method is useful for exploring, describing and predicting relationships between variables by grouping (De'ath, 2002), simplifying the analysis of complex ecological data that often includes disequilibrium, missing values, non-linear relationships between variables and high-order interactions, and these groupings enable patterns to be predicted using only the available variable data (De'ath, 2002). In this method, leaves of the tree are characterized by an estimate of the mean number of individuals, mean squared error (MSE), number of observations in the cross-validation $(\mathrm{N})$ and complexity parameter (CP). MRT were performed using the package mvpart (function mvpart(); Therneau et al., 2007) run under the GNU-R (R Development Core Team, 2016). The normality of the data was tested using the Kolmogorov-Smirnov test, and the data were ln-transformed when necessary.

Phylloicus sp. density and the variables selected by the MRT model were compared between months (categorical variable) by Repeated Measures Analysis of Variance (rm-ANOVA) using the package stats (function $\operatorname{lm}()$ ) in GNU-R (R Development Core Team, 2016). Sampling plots were used as a correction factor for pseudo replicates in the rm-ANOVA. Contrast analyses were carried out to discriminate among statistically significant categorical variables. In this contrast analysis (orthogonal), the months were ordered (increasingly) and tested pairwise (with the closest values) and sequentially adding to the model treatment values with no differences and testing with the next in a steps model simplification (for more details, see chapter 9 in Crawley, 2007).

\section{Results}

Monthly accumulated rainfall varied from $0 \mathrm{~mm}$ to $396 \mathrm{~mm}$, with highest values in November and January and no precipitation registered in July and August. Mean discharge was $0.72 \mathrm{~m}^{3} \cdot \mathrm{s}^{-1}$ $( \pm 0.7 \mathrm{SD})$, and water temperature ranged from 16 to $22^{\circ} \mathrm{C}$ (mean $\left.19.4^{\circ} \mathrm{C} \pm 2.2 \mathrm{SD}\right)$. Stream water was circumneutral $(\mathrm{pH}=7.1 \pm 0.8$, mean $\pm \mathrm{SD}$ ), with high dissolved oxygen (7.9 mg. $\left.1^{-1} \pm 1.9 \mathrm{SD}\right)$, low electrical conductivity $\left(5.1 \mu \mathrm{S} . \mathrm{cm}^{-1} \pm 3.6\right)$ and low turbidity (4.9 NTU \pm 2.9$)$. Electrical conductivity varied over time ( $\mathrm{rm}$-ANOVA, $\mathrm{F}_{11,42}=7.61$; $\mathrm{p}<0.001)$ and was significantly high in December when compared to other months (Contrast Analysis; $\mathrm{p}<0.001)$.

Leaves was the category that most contributed to total coarse particulate organic matter $(-70 \%)$, in both compartments (vertical input and benthic stock; Figure 2). Average monthly biomass of leaves was $24.2 \mathrm{~g} \cdot \mathrm{m}^{-2}( \pm 23.1 \mathrm{SD})$ in the vertical input and $46.1 \mathrm{~g} \cdot \mathrm{m}^{-2}( \pm 76.7 \mathrm{SD})$ in the benthic standing stock, while the total input was $70.3 \mathrm{~g} \cdot \mathrm{m}^{-2}\left(843.6 \mathrm{~g} \cdot \mathrm{m}^{-2}\right.$. year; Figure $3 \mathrm{~A}$ ). Branches were more common in the benthic stock than in the vertical input, mainly in August (45.3 g. $\mathrm{m}^{-2}$ ). Leaves biomass from the VI differ among months (rm-ANOVA, $\left.\mathrm{F}_{9,43}=6.21 ; \mathrm{p}<0.001\right)$ with highest values in October $\left(67.9 \pm 45\right.$ g.m ${ }^{-2}$, mean \pm SD; Contrast analyses; $\mathrm{p}<0.001)$, followed by September (49.6 g. $\left.\mathrm{m}^{-2} \pm 23 \mathrm{SD}\right)$. Reproductive parts had a low monthly contribution of both vertical input $\left(3.1 \pm 2.1\right.$ g. $\mathrm{m}^{-2}$, mean $\left.\pm \mathrm{SD}\right)$ and benthic stock 
$\left(1.7 \pm 3.7 \mathrm{~g} \cdot \mathrm{m}^{-2}\right.$, mean $\left.\pm \mathrm{SD}\right)$. VI samples from November were lost due an abrupt hydrological variation (flood), which carried away our bucket samplers.

A total of 217 individuals of Phylloicus sp. were counted. The density changed between months

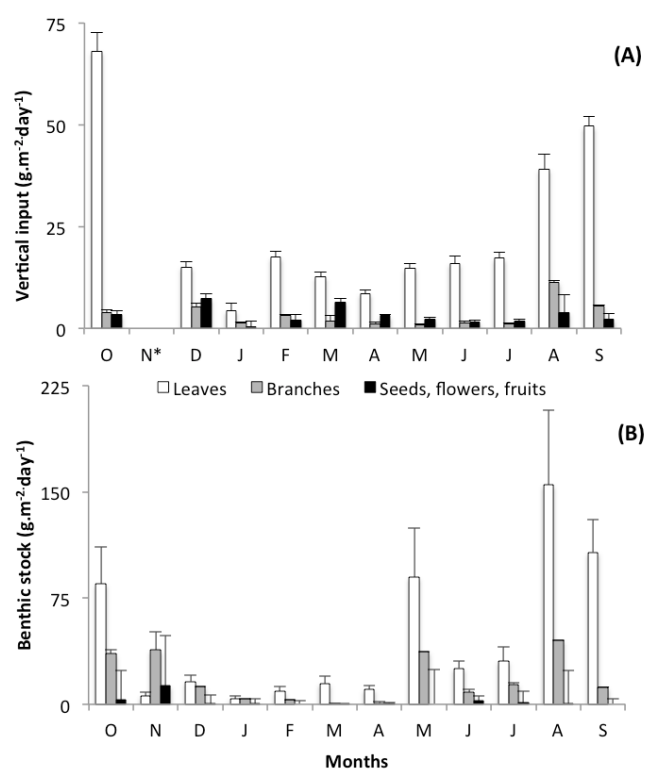

Figure 2. Mean (and standard error) daily CPOM (leaves, branches and reproductive parts) in the vertical input (A) and benthic stock (B) for each month (between October 2012 and September 2013) in the Capetinga stream. ${ }^{*}$ Missing data.

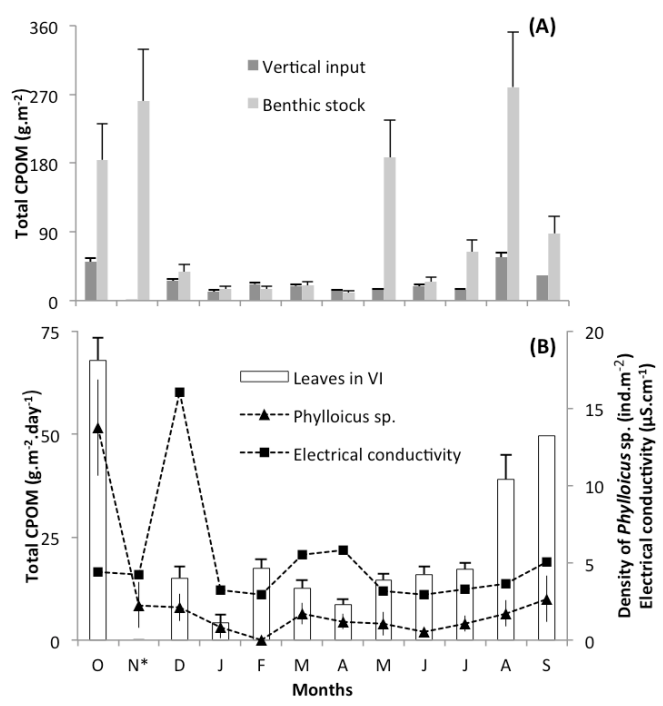

Figure 3. (A) Total CPOM (mean and standard error) in vertical input and benthic stock; (B) mean daily CPOM of leaves in VI, electrical conductivity and Phylloicus sp. density estimated for each month (between October 2012 and September 2013) in the Capetinga stream. *Missing data. $\left(2.4 \pm 4.9\right.$ ind $\mathrm{m}^{2}$, mean $\pm \mathrm{SD}$; rm-ANOVA, $\left.\mathrm{F}_{10,48}=4.38, \mathrm{p}<0.001\right)$, with the highest value in October $\left(13.7 \pm 11.2\right.$ ind. $\mathrm{m}^{2}$, mean $\pm \mathrm{SD}$; Contrast analyses; $\mathrm{p}<0.001$; Figure 3B). No individuals were found in February.

The regression tree model indicated that variability in Phylloicus sp. density in the Capetinga stream may be attributed to leaves in VI and electrical conductivity (Figure 4). The model predicts that Phylloicus sp. density may be as high as 8.2 ind. $\mathrm{m}^{-2}$ if leaves biomass in VI is greater than or equal to 44.3 g. $\mathrm{m}^{-2}$ (prediction $\mathrm{MSE}=30.6$; $\mathrm{cp}=0.55$ ). Density of Phylloicus sp. can be as low as 0.7 ind. $\mathrm{m}^{-2}$ if stream electrical conductivity is less than $3.5 \mathrm{mS} . \mathrm{cm}^{-1}$ and leaves biomass in VI less than $44.3 \mathrm{~g} \cdot \mathrm{m}^{-2}$ (prediction MSE $=0.15$; $\mathrm{cp}=0.02$ ). However, high rates of stand leaves in benthic stock in the dry season (August; $154.9 \pm 203.2$ g. $\mathrm{m}^{-2}$ ) showed no significant association with Phylloicus sp. density.

\section{Discussion}

The average density of Phylloicus sp. observed in this study (2.4 ind. $\mathrm{m}^{2}$; 0.05 ind. $\mathrm{g}^{-1}$ of leaf litter) is lower than that of other tropical streams (1.3 ind. $\mathrm{g}^{-1}$ in Boyero et al., 2011) and temperate streams (3.4 ind. $\mathrm{g}^{-1}$ in Boyero et al., 2011). Our results corroborate the trend of low shredder abundance in tropical streams (Graça, 2001; Gonçalves Júnior et al., 2007). In an evolutionary perspective, the main hypotheses for the low density of Phylloicus sp. in tropical streams are: i) the higher water temperatures (Dobson et al., 2002; Boyero et al., 2011; Navarro et al., 2013); ii) lower availability of high-quality leaf litter (Wantzen \& Wagner, 2006; Boyero et al., 2011, 2012; Rawi et al., 2013;

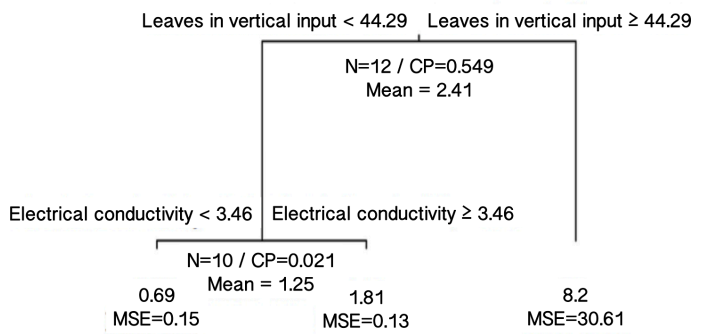

Figure 4. Fitted regression tree showing best predictors of Phylloicus sp. density (ind. $\mathrm{m}^{-2}$ ) between October 2012 and September 2013 and hierarchical relationship among the predictors (electrical conductivity in $\mu S . \mathrm{cm}^{-1}$ and organic matter fractions in ind. $\mathrm{m}^{-2}$ ). Terminal nodes of the tree with mean estimated number of individuals, mean squared error (MSE), number of observations in the cross-validation $(\mathrm{N})$ and complexity parameter $(\mathrm{CP})$. 
Graça et al., 2015); and iii) negative ecological interactions (e.g., competition and predation; Navarro et al., 2013; Rezende et al., 2015). Shredders belonging to orders Plecoptera and Trichoptera evolved in cold environments (Merritt \& Cummins, 1996) and the low tolerance to higher temperatures imply lower abundance in tropical streams (Dobson et al., 2002; Boyero et al., 2012; Navarro et al., 2013). Additionally, the low quality of leaf litter in the tropics (high concentrations of secondary or refractory metabolites) exerts a bottom-up control on shredder populations. On the other hand, the large bodies (high biomass) of some typical shredders, such as Phylloicus, and consequently their higher consumption rates per capita may compensate for their relatively low abundance, indicating the need for estimates based on invertebrate biomass (Tonin et al., 2014). However, recent information is still insufficient to define patterns of distribution of shredders in tropical stream systems and aspects such as the occurrence of a species at a specific site are still unknown (Boyero et al., 2012).

The observed relationship between Phylloicus sp. density and leaf litter suggests a dependence of the population on allochthonous organic matter input, with highest density in October (peak of leaf input) and reduced abundance in periods of lower leaf input. This is consistent with positive relationships between organic matter and shredder density in previous experiments (Grafius \& Anderson, 1980; Graça, 2001) and manipulative studies (Cuffney et al., 1990; Lugthart \& Wallace, 1992; Hall Junior et al., 2000). Rezende et al. (2015) experimentally examined the effects of increased density of Phylloicus sp. on processing of leaf litter and hypothesized that at high densities, this species is forced to compete intraspecifically for preferential resources and may, most likely, initiate attacks to protect the food source. This behavior may be further stimulated by the low availability and low-quality of food resources in the environment (Moretti et al., 2009; Rezende et al., 2015).

The benthic standing stock is not directly related with Phylloicus sp. density. There are two main ecological reasons that may explain this finding. Firstly, abrupt hydrological variation (e.g. floods) are common in the Brazilian savannah headwaters during the rainy season. Floods can flush out much of the CPOM stored in the standing benthic stock in a short time, modifying the local natural conditions (e.g. resource availability) in the stream reach, but not Phylloicus sp. density due to the capacity of this taxon to adhere to the substrate. Secondly, studies on organic matter dynamics in tropical riparian zones have demonstrated high plant species diversity (Gregório et al., 2007; França et al., 2009; Gonçalves Júnior et al., 2014), with changes in the relative importance among plant species throughout the year due to differences in senescence (Gonçalves Júnior \& Callisto, 2013; Gonçalves Júnior et al., 2014). Whereas some types of detritus are more attractive to invertebrates than others, as a function of their chemical composition (Rincón \& Martínez, 2006; Moretti et al., 2009; Navarro et al., 2013), the available litter mixture may vary in its chemical composition through the year. Therefore, due to the peak of leaf litter input at the end of the dry season (Rezende et al., 2016), there is an increase in plant diversity in the litterfall and a higher probability of palatable species input at this time (Lima \& Gonçalves Júnior, 2015). Therefore, we can hypothesize that: i) Phylloicus sp. has an intricate species-specific association with the input of high quality leaf species (or mixture) or a single key species; and ii) the distribution of Phylloicus sp. in Brazilian savannah streams may correspond to areas where high quality plant species are abundant and its major productivity period corresponds to time of maximum availability of specific deciduous leaves. Alternatively, similar patterns of availability/abundance between VI and BS can produce a multicollinearity between these variables, causing the regression tree model to discard the variable with the least potential explanation for variation in the density of Phylloicus.

Apart from the leaves in VI, the electrical conductivity was also responsible for driving the density of Phylloicus sp. The increase in electrical conductivity reflects ion concentrations in the water and may indicate an increase in nutrient concentrations in the stream, (i.e., nitrogen, phosphorous and carbon), which are associated with nutrients liberated/produced directly or indirectly by the breakdown process (Gessner et al., 1999; Bae et al., 2011; Rezende et al., 2014). Furthermore, higher values of nutrient concentrations are important for micro-organisms (fungi, bacteria, algae and other), stimulating biofilm formation on detritus (Suberkropp \& Chauvet, 1995; Benstead et al., 2009). Higher micro-organism biomass and biofilm production may increase the palatability of detritus, as well as its nutritional quality, for shredders such as Phylloicus sp. (Suberkropp \& Chauvet, 1995; Benstead et al., 2009; Bae et al., 2011). Shredders feed more and 
grow better on leaf litter that has been leached and colonized by microbes (Moretti et al., 2009; Gonçalves Júnior et al., 2013). Detrital nutritional values may be responsible for changes in foraging patterns of shredders, increasing consumption and processing rates of allochthonous organic matter (Moretti et al., 2009). This intricate process may explain the positive relationship between electrical conductivity in water and Phylloicus sp. density. However, our data are insufficient to support the hypothesis that there is an increase in the nutritional value of available detritus during certain seasons or to evidence a bottom-up effect. Therefore, future research should be conducted with this purpose.

\section{Acknowledgements}

We are grateful to PROCAD-NF/CAPES (No. 173/2010), CAPES/Edital PNADB/2009 (No. 1098/2010), MCTI/CNPq No. 14/2013 - Universal / Universal 14/2013 (No. 471767/2013-1), CNPq/Bolsas PQ (No. 302957/2014-6) MCTI/PELD/CNPq (No. 558233/2009-0), MCTI/CNPq/CT-AGRO/CTSAÚDE/CT-HIDRO (No. 37/2013), MCT/CNPq/ FNDCT/FAPs/MEC/CAPES/PRO-CENTRO-OESTE (No. 031/2010), EMBRAPA/Edital Chamada 01/2011, FAP-DF/Edital 03/2015 (No. 193.000.870/2015); FAPEMIG (No. APQ-00274-12), FAP-DF/Edital 01/2016 (Protocolo No. 8902.54.34645.12022016), and funds of the University of Brasilia (UnB) (DPP; No. 121366/2011) for the financial support. We are also grateful for the concession of a Post-Doctoral Scholarship from the program in Ecology and Conservation of the State University of Mato Grosso in Nova Xavantina-MT (CAPES/PNPD) to RS Rezende. The first author also received a scholarship from CAPES during his $\mathrm{PhD}$ research in the Graduate Program in Ecology of UnB. Finally, we would like to express our special gratitude to the entire Aquariparia group for their outstanding support throughout the study.

\section{References}

ABELHO, M. From litterfall to breakdown in streams: a review. The Scientific World Journal, 2001, 1, 656-680. http://dx.doi.org/10.1100/tsw.2001.103. PMid:12805769.

ALLAN, K., BOYERO, L. and PEARSON, R. Chemical communication in competitive interactions among tropical stream detritivores. Tropical Zoology, 2009, 22(1), 195-204.

BAE, M.J., KWON, Y., HWANG, S.J., CHON, T.S., YANG, H.J., KWAK, I.S., PARK, J.H., HAM, S.A. and PARK, Y.S. Relationships between three major stream assemblages and their environmental factors in multiple spatial scales. Annales de Limnologie - International"Journal of Limnology, 2011, 47, S91-S105. http://dx.doi.org/10.1051/ $\operatorname{limn} / 2011022$.

BECKER, B., MORETTI, M.S. and CALLISTO, M. Length-dry mass relationships for a typical shredder in Brazilian streams (Trichoptera: Calamoceratidae). Aquatic Insects, 2009, 31(3), 227-234. http://dx.doi. org/10.1080/01650420902787549.

BENSON, L. and PEARSON, R.G. Litter inputs to a tropical Australian rainforest stream. Australian Journal of Ecology, 1993, 18(4), 377-383. http:// dx.doi.org/10.1111/j.1442-9993.1993.tb00465.x.

BENSTEAD, J.P., ROSEMOND, A.D., CROSS, W.F., WALLACE, J.B., EGGERT, S.L., SUBERKROPP, K., GULIS, V., GREENWOOD, J.L. and TANT, C.J. Nutrient enrichment alters storage and fluxes of detritus in a headwater stream ecosystem. Ecology, 2009, 90(9), 2556-2566. http://dx.doi. org/10.1890/08-0862.1. PMid:19769133.

BOYERO, L. and PEARSON, R.G. Intraspecific interference in a tropical stream shredder guild. Marine \& Freshwater Research, 2006, 57(2), 201-206. http://dx.doi.org/10.1071/MF05052.

BOYERO, L., PEARSON, R.G., DUDGEON, D., FERREIRA, V., GRAÇA, M.A.S., GESSNER, M.O., BOULTON, A.J., CHAUVET, E., YULE, C.M., ALBARIÑO, R.J., RAMÍREZ, A., HELSON, J.E., CALLISTO, M., ARUNACHALAM, M., CHARÁ, J., FIGUEROA, R., MATHOOKO, J.M., GONÇALVES JÚNIOR, J.F., MORETTI, M.S., CHARÁ-SERNA, A.M., DAVIES, J.N., ENCALADA, A., LAMOTHE, S., BURIA, L.M., CASTELA, J., CORNEJO, A., LI, A.O.Y., M'ERIMBA, C., VILLANUEVA, V.D., DEL CARMEN ZÚNIIGA, M., SWAN, C.M. and BARMUTA, L.A. Global patterns of stream detritivore distribution: implications for biodiversity loss in changing climates. Global Ecology and Biogeography, 2012, 21(2), 134-141. http://dx.doi. org/10.1111/j.1466-8238.2011.00673.x.

BOYERO, L., PEARSON, R.G., DUDGEON, D., GRAÇA, M.A.S., GESSNER, M.O., ALBARINO, R.J., FERREIRA, V., YULE, C.M., BOULTON, A.J., ARUNACHALAM, M., CALLISTO, M., CHAUVET, E., RAMIREZ, A., CHARA, J., MORETTI, M.S., GONÇALVES JÚNIOR, J.F., HELSON, J.E., CHARA-SERNA, A.M., ENCALADA, A.C., DAVIES, J.N., LAMOTHE, S., CORNEJO, A., LI, A.O.Y., BURIA, L.M., VILLANUEVA, V.D., ZUNIGA, M.C. and PRINGLE, C.M. Global distribution of a key trophic guild contrasts with common latitudinal diversity patterns. Ecology, 2011, 92(9), 1839-1848. http:// dx.doi.org/10.1890/10-2244.1. PMid:21939080. 
CRAWLEY, M.J. The R Book. UK: John Wiley \& Sons, 2007.

CUFFNEY, T.F., WALLACE, J.B. and LUGTHART, G.J. Experimental evidence quantifying the role of benthic invertebrates in organic matter dynamics of headwater streams. Freshwater Biology, 1990, 23(2), 281-299. http://dx.doi. org/10.1111/j.1365-2427.1990.tb00272.x.

CUMMINS, K.W. The importance of different energy sources in freshwater ecosystems. In D.E. REICHLE, J.F. FRANKLIN and D.W. GOODALL, eds. Productivity of world ecosystems. Washington: Proc. Symp. IBP General Assembly Nat. Acad. Sci., 1975, pp. 50-54.

DE'ATH, G. Multivariate Regression Trees: a new technique for modeling species-environment relationships. Ecology, 2002, 83(4), 1105-1117.

DOBSON, M., MATHOOKO, J.M., MAGANA, A. and NDEGWA, F.K. Detritivores in Kenyan highland streams: more evidence for the paucity of shredders in the tropics? Freshwater Biology, 2002, 47(5), 909-919. http://dx.doi.org/10.1046/j.13652427.2002.00818.x.

FRANÇA, J.S., GREGÓRIO, R.S., D’ARC DE PAULA, J., GONÇALVES JÚNIOR, J.F., FERREIRA, F.A. and CALLISTO, M. Composition and dynamics of allochthonous organic matter inputs and benthic stock in a Brazilian stream. Marine \& Freshwater Research, 2009, 60(10), 990-998. http://dx.doi. org/10.1071/MF08247.

GESSNER, M.O., CHAUVET, E. and DOBSON, M. A perspective on leaf-breakdown in streams. Oikos, 1999, 85(2), 377-384. http://dx.doi. org/10.2307/3546505.

GONÇALVES JÚNIOR, J.F. and CALLISTO, M. Organic-matter dynamics in the riparian zone of a tropical headwater stream in Southern Brasil. Aquatic Botany, 2013, 109(1), 8-13. http://dx.doi. org/10.1016/j.aquabot.2013.03.005.

GONÇALVES JÚNIOR, J.F., FRANÇA, J.S. and CALLISTO, M. Dynamics of allochthonous organic matter in a tropical Brazilian headstream. Brazilian Archives of Biology and Technology, 2006, 49(6), 967-973. http://dx.doi.org/10.1590/S151689132006000700014

GONÇALVES JÚNIOR, J.F., GRAÇA, M.A.S. and CALLISTO, M. Litter decomposition in a Cerrado savannah stream is retarded by leaf toughness, low dissolved nutrients and a low density of shredders. Freshwater Biology, 2007, 52(8), 1440-1451. http:// dx.doi.org/10.1111/j.1365-2427.2007.01769.x.

GONÇALVES JÚNIOR, J.F., MARTINS, R.T., OTTONI, B.M.P. and COUCEIRO, S.R.M. Uma visão sobre a decomposição foliar em sistemas aquáticos brasileiros. In N. HAMADA, J.L. NESSIMIAN and R.B. QUERINO, eds. Insetos aquáticos na Amazônia Brasileira: taxonomia, biologia e ecologia. Manaus: INPA, 2013, pp. 1-41.

GONÇALVES JÚNIOR, J.F., REZENDE, R.S., MARTINS, N.M. and GREGORIO, R.S. Leaf breakdown in an Atlantic Rain Forest stream. Austral Ecology, 2012a, 37(7), 807-815. http://dx.doi. org/10.1111/j.1442-9993.2011.02341.x.

GONÇALVES JÚNIOR, J.F., REZENDE, R.S., FRANÇA, J.S. and CALLISTO, M. Invertebrate colonisation during leaf processing of native, exotic and artificial detritus in a tropical stream. Marine \& Freshwater Research, 2012b, 63(5), 428-439. http:// dx.doi.org/10.1071/MF11172.

GONÇALVES JÚNIOR, J.F., REZENDE, R.S., GREGÓRIO, R.S. and VALENTIN, G.C. Relationship between dynamics of litterfall and riparian plant species in a tropical stream. Limnologica: Ecology and Management of Inland Waters, 2014, 44, 40-48. http://dx.doi.org/10.1016/j. limno.2013.05.010.

GRAÇA, M.A.S. The role of invertebrates on leaf litter decomposition in streams: a review. International Review of Hydrobiology, 2001, 4(5), 383-394. http://dx.doi. org/10.1002/1522-2632(200107)86:4/5<383::AIDIROH383>3.0.CO;2-D.

GRAÇA, M.A.S., FERREIRA, V., CANHOTO, C., ENCALADA, A.C., GUERRERO-BOLAÑO, F., WANTZEN, K.M. and BOYERO, L. A conceptual model of litter breakdown in low order streams. International Review of Hydrobiology, 2015, 100(1), 1-12. http://dx.doi.org/10.1002/iroh.201401757.

GRAFIUS, E. and ANDERSON, N.H. Population dynamics, bioenergetics, and role of Lepidostoma quercina Ross (Trichoptera: Lepidostomatidae) in an Oregon woodland stream. Ecology, 1979, 60(2), 433-441. http://dx.doi.org/10.2307/1937670.

GRAFIUS, E. and ANDERSON, N.H. Populations dynamics and role of two species of Lepidostoma (Trichoptera: Lepidostomatidae) in an Oregon coniferous forest stream. Ecology, 1980, 61(4), 808816. http://dx.doi.org/10.2307/1936751.

GREGÓRIO, R.S., VALENTIN, G., FERREIRA, F.A., ALEIXO, L.A., FRANÇA, J.S., GONÇALVES JÚNIOR, J.F., CALLISTO, M., BATISTA, M.L., GASPAR, R.O. and RODELLO, C.M. Contribuiçâao foliar alóctone de espécies vegetais num córrego de $2^{a}$ ordem na Estação Ambiental de Peti (CEMIG) - MG. Revista Brasileira de Biociências, 2007, 5(S1), 33-35.

HAAPALA, A., MUOTKA, T. and MARKKOLA, A. Breakdown and macroinvertebrate and fungal colonization of alder, birch, and willow leaves in a boreal forest stream. Journal of the North American Benthological Society, 2001, 20(3), 395-407. http:// dx.doi.org/10.2307/1468037. 
HALL JUNIOR, R.O., WALLACE, J.B. and EGGERT, S.L. Organic matter flow in stream food webs with reduced detrital resource base. Ecology, 2000, 81(12), 3445-3463. http://dx.doi.org/10.1890/00129658(2000)081[3445:OMFISF]2.0.CO;2.

KOBAYASHI, S. and KAGAYA, T. Litter patch types determine macroinvertebrate assemblages in pools of a Japanese headwater stream. Journal of the North American Benthological Society, 2004, 23(1), 78-89. http://dx.doi.org/10.1899/08873593(2004)023<0078:LPTDMA>2.0.CO;2.

KOBAYASHI, S. and KAGAYA, T. Hot spots of leaf breakdown within a headwater stream reach: comparing breakdown rates among litter patch types with different macroinvertebrate assemblages. Freshwater Biology, 2005, 50(6), 921-929. http:// dx.doi.org/10.1111/j.1365-2427.2005.01371.x.

LIGEIRO, R., MORETTI, M.S., GONÇALVES JÚNIOR, J.F. and CALLISTO, M. What is more important for invertebrate colonization in a stream with low-quality litter inputs: exposure time or leaf species? Hydrobiologia, 2010, 654(1), 125-136. http://dx.doi.org/10.1007/s10750-010-0375-8.

LIMA, L.S. and GONÇALVES JÚNIOR, J.F. Heterogeneidade temporal e espacial na composição química do detrito foliar. In Livro de resumos do II Simpósio Processos Ecológicos, Restauração e Ecovaloração em Zonas Ripárias (AquaRipária). Brasília: AquaRipária, 2015, pp. 12-15.

LUGTHART, G.J. and WALLACE, J.B. Effects of disturbance on benthic functional structure and production in mountain streams. Journal of the North American Benthological Society, 1992, 11(2), 138-164. http://dx.doi.org/10.2307/1467381.

MERRITT, R.W. and CUMMINS, K.W. An introduction to the aquatic insects of North America. Dubuque: Kendall/Hunt Publishing Company, 1996.

MORETTI, M., GONÇALVES JÚNIOR, J.F. and CALLISTO, M. Leaf breakdown in two tropical streams: differences between single and mixed species packs. Limnologica, 2007, 37(3), 250-258. http:// dx.doi.org/10.1016/j.limno.2007.01.003.

MORETTI, M.S., LOYOLA, R.D., BECKER, B. and CALLISTO, M. Leaf abundance and phenolic concentrations codetermine the selection of casebuilding materials by Phylloicus sp. (Trichoptera, Calamoceratidae). Hydrobiologia, 2009, 630(1), 199206. http://dx.doi.org/10.1007/s10750-009-9792-y.

NAVARRO, F.K.S.P., REZENDE, R.S. and GONCALVES JUNIOR, J.F. Experimental assessment of temperature increase and presence of predator carcass changing the response of invertebrate shredders. Biota Neotropica, 2013, 13(4), 1-6. http:// dx.doi.org/10.1590/S1676-06032013000400002.

PES, A.M.O., VIDOVIX, T.A.S., MARTINS, R.T. and DUARTE, C. Use of leaves treated with hydrogen peroxide in case-building by Phylloicus spp. (Trichoptera: Calamoceratidae). EntomoBrasilis, 2013, 6(1), 39-41. http://dx.doi.org/10.12741/ ebrasilis.v6i1.267.

PRATHER, A.L. Revision of the Neotropical caddisfly genus Phylloicus (Trichoptera: Calamoceratidae). Zootaxa, 2003, 275(1), 1-214.

R DEVELOPMENT CORE TEAM. $R$ : a language and environment for statistical computing. Version 3.3.0 [software]. Vienna: R Foundation for Statistical Computing, 2016. [viewed 08 Mar. 2016]. Available from: https://www.R-project.org/

RAWI, C.S.M., AL-SHAMI, S.A., MADRUS, M.R. and AHMAD, A.H. Local effects of forest fragmentation on diversity of aquatic insects in tropical forest streams: implications for biological conservation. Aquatic Ecology, 2013, 47(1), 75-85. http://dx.doi. org/10.1007/s10452-012-9426-8.

REZENDE, R.S., GRAÇA, M.A.S., SANTOS, A.M., MEDEIROS, A.O., SANTOS, P.F., NUNES, Y.R. and GONÇALVES JÚNIOR, J.F. Organic matter dynamics in a tropical gallery forest in a grassland landscape. Biotropica, 2016, 48(3), 301-310. http:// dx.doi.org/10.1111/btp.12308.

REZENDE, R.S., LEITE, G.F.M., DE-LIMA, A.K.S., SILVA-FILHO, L.A.B., CHAVES, C.V.C., PRETTE, A.C.H., FREITAS, J.S. and GONÇALVES JÚNIOR, J.F. Effects of density and predation risk on leaf litter processing by Phylloicus sp. Austral Ecology, 2015, 40(6), 693-700. http:// dx.doi.org/10.1111/aec.12236.

REZENDE, R.S., PETRUCIO, M.M. and GONÇALVES JÚNIOR, J.F. The effects of spatial scale on breakdown of leaves in a tropical watershed. PLoS One, 2014, 9(5), e97072. http:// dx.doi.org/10.1371/journal.pone.0097072. PMid:24810918.

RICHARDSON, J.S. Limits to productivity in streams: evidence from studies of macroinvertebrates. Canadian Special Publication of Fisheries and Aquatic Sciences, 1993, 39(4), 9-15.

RINCÓN, J. and MARTÍNEZ, I. Food quality and feeding preferences of Phylloicus sp. (Trichoptera: Calamoceratidae). Journal of the North American Benthological Society, 2006, 25(1), 209-215. http:// dx.doi.org/10.1899/0887-3593(2006)25[209:FQA FPO]2.0.CO;2.

SUBERKROPP, K. and CHAUVET, E. Regulation of leaf breakdown by fungi in streams: influences of water chemistry. Ecology, 1995, 76(5), 1433-1445. http://dx.doi.org/10.2307/1938146.

TANK, J.L., ROSI-MARSHALL, E.J., GRIFFITHS, N.A., ENTREKIN, S.A. and STEPHEN, M.L. A review of allochthonous organic matter dynamics and metabolism in streams. Journal of the North American 
Benthological Society, 2010, 29(1), 118-146. http:// dx.doi.org/10.1899/08-170.1.

THERNEAU, T.M., ATKINSON, B., RIPLEY, B., OKSANEN, J. and DE'ATH, G. Mvpart: multivariate partitioning. $R$ package version 1.2-6 [software]. Bayreuth: University of Bayreuth, 2007.

TONIN, A.M., HEPP, L.U., RESTELLO, R.M. and GONÇALVES JÚNIOR, J.F. Understanding of colonization and breakdown of leaves by invertebrates in a tropical stream is enhanced by using biomass as well as count data. Hydrobiologia, 2014, 740(1), 7988. http://dx.doi.org/10.1007/s10750-014-1939-9.

WANTZEN, K.M. and WAGNER, R. Detritus processing by invertebrate shredders: a neotropical- temperate comparison. Journal of the North American Benthological Society, 2006, 25(1), 216-232. http:// dx.doi.org/10.1899/0887-3593(2006)25[216:DPB ISA]2.0.CO;2.

WEBSTER, J.R. and BENFIELD, E.F. Vascular plant breakdown in freshwater ecosystems. Annual Review of Ecology and Systematics, 1986, 17(1), 567-594. http://dx.doi.org/10.1146/annurev. es.17.110186.003031.

Received: 08 March 2016

Accepted: 30 August 2016 